\title{
Big Data Technology Accounting File Management Based on Financial Sharing Mode
}

\author{
Liu Yonghong \\ Shandong Administration College, Shandong, China
}

Keywords: File informationization, big data, file management, financial sharing mode

Abstract: In recent years, with the emergence of new technologies and new concepts such as big data, "Internet +", cloud computing, cloud accounting, etc., the purpose of establishing financial sharing service centers is not only to improve efficiency, reduce costs, and streamline Basic progress such as personnel, but gradually transform it into important roles such as the profit center, data center, and strategic center of the enterprise, and maximize the value of the financial shared service center. Based on the era of big data, this paper expounds the necessity of the transition from financial shared service center to data center and the practical problems it faces.

\section{Introduction}

With the continuous improvement of the current engineering document management in China, the processing of its informationization has become more and more effective. The file management informationization can improve the quality of the project or practice project to a certain extent, and can use the information technology to establish the project file management account as quickly as possible, so that the overall file retrieval is more accurate and the overall resource sharing is realized. The advantage of digital retrieval of files is that they are faster to retrieve, and it is easier to achieve synchronized backups. The storage takes up less space and is more convenient and safe to maintain. Therefore, the archival information construction of the project is of great significance to the engineering process and quality.

\section{The necessity of accounting files information construction based on financial sharing mode}

In the current construction process of China's engineering projects, large-scale projects are generally composed of more construction links. These include the project bidding group, the basic design, installation and commissioning, and on-site test run. The document management in the project is the archived text information, drawings and other documents that are composed from the beginning of the project to the end of the project. These are the basis for recording the project management process. Therefore, in the construction of the project, it is necessary to further manage, collect and organize the archives, so as to ensure the complete and accurate construction of the larger accounting files based on the financial sharing model, and this has become the level of engineering technology management in China. The important component of the information processing of accounting files based on the financial sharing model is a very important part of the 
file processing.

\section{Contents of accounting file management informationization based on financial sharing mode}

\subsection{Problems in Accounting File Management Based on Financial Sharing Mode}

\subsubsection{Archives laws and regulations are difficult to provide guidance for each project}

In recent years, Chinese government departments have proposed and issued some legal provisions on file management. These laws and regulations can regulate enterprise project projects in a more standardized way.

\begin{tabular}{|c|c|c|c|}
\hline \multirow{6}{*}{$\begin{array}{l}\text { Investing / } \\
\text { increasing the } \\
\text { ability within } \\
\text { the company }\end{array}$} & $\begin{array}{l}\text { Group business } \\
\text { function }\end{array}$ & Financial function & Area of concern \\
\hline & $\begin{array}{r}\text { Strategic } \\
\text { Planning }\end{array}$ & $\begin{array}{l}\text { Financial strategy } \\
\text { and planning }\end{array}$ & \multirow{4}{*}{$\begin{array}{l}\text { Increased focus on areas related to the } \\
\text { Group's operations and development: } \\
\text { The planned budget is fully } \\
\text { integrated with the Group's } \\
\text { business operations, internal and } \\
\text { external performance indicators are } \\
\text { broken down into the business layer } \\
\text { by layer. }\end{array}$} \\
\hline & $\begin{array}{l}\text { Business } \\
\text { integration }\end{array}$ & Total budget & \\
\hline & $\begin{array}{l}\text { Value } \\
\text { management }\end{array}$ & $\begin{array}{l}\text { Performance } \\
\text { management }\end{array}$ & \\
\hline & $\begin{array}{l}\text { Capital } \\
\text { operation }\end{array}$ & $\begin{array}{l}\text { Investment } \\
\text { management }\end{array}$ & \\
\hline & $\begin{array}{c}\text { human resource } \\
\text { Management }\end{array}$ & Fund management & \multirow{2}{*}{$\begin{array}{l}\text { Ability to access real-time access to } \\
\text { analytical information that identifies } \\
\text { business development opportunities }\end{array}$} \\
\hline $\begin{array}{r}\text { Internal } \\
\text { sharing/out } \\
\text { sourcing }\end{array}$ & $\begin{array}{l}\text { Business } \\
\text { expansion }\end{array}$ & Cost accounting & \\
\hline
\end{tabular}

Figure 1: The impact of archival laws and regulations on various projects

\subsubsection{It is difficult for enterprises to keep up with the development speed of archives construction}

With the continuous development of the "Thirteenth Five-Year Plan", most enterprises in China are actively improving and perfecting their own file management. The scale of enterprise construction is increasing, which will also increase the quality requirements of file management. The management of archives is an important part of project management. At the same time, because it is a relatively clear management work in the project, the management of project engineering needs to be carried out from multiple angles at the same time. The management system of project archives not only needs its own foundation and service role as the foundation, but also needs to establish a complete set of perfect file management system. At present, China's science and technology level and information level are still not perfect. Some enterprises still follow the traditional management methods in the accounting file management based on the financial sharing mode, so the program that does not use advanced management technology is not suitable for the development of file management. .

\subsubsection{Project archive management construction system needs to be improved}

At present, China's engineering field has gradually been completed. Some enterprises have gradually found their own scale and system in the process of project construction, but they still need to be upgraded in some places. In general, the accounting file management system based on the 
financial sharing model of the current enterprises in China mainly presents a pyramidal arrangement. At the top of the pyramid is the archives management law "Archives Law" currently issued in China, and at this level, the basic working principles of file management are clearly put forward, and a more specific management direction is proposed for the management of archives. The second layer of the pyramid is the administrative regulations issued by local governments at all levels. These mainly propose more practical management plans and systems. The next step is the management rules and regulations of archives, which mainly provide enterprises with practical management methods. At the bottom is the specific file management strategy developed by different companies based on their own situation.

\subsection{Digital Network Construction of Accounting File Management Based on Financial Sharing Mode}

The so-called digital network construction of file management, which is, through computer technology, OCR technology and new technologies in digital photography, storage technology, multimedia technology, etc., the file resources of various carriers are converted into digital information, and stored in digital form. Connect in the form of a network to build a holistic and orderly archive information management library, which can be provided to users in a timely manner and achieve reasonable sharing of resources. After the project document digitization process is completed, the document number can be correctly entered into the electronic management system, thereby ensuring the correspondence of the entries and the graphics.

In addition, companies can use the actual situation of the project scale as the basis to develop or purchase the corresponding electronic file management technology, equipped with certain servers and data, and use the $\mathrm{B} / \mathrm{S}$ architecture to deliver documents at different times. Documents can be used as projects.

\subsection{Database technology makes full use of accounting file information management based on financial sharing mode}

The goal of database technology in engineering information management is to solve the problem of data information collection, storage, access and processing. And in the management of the project document, the database is used to store, retrieve and maintain the archive information, so that the user can obtain the corresponding information in the file to maximize the efficiency of file management.

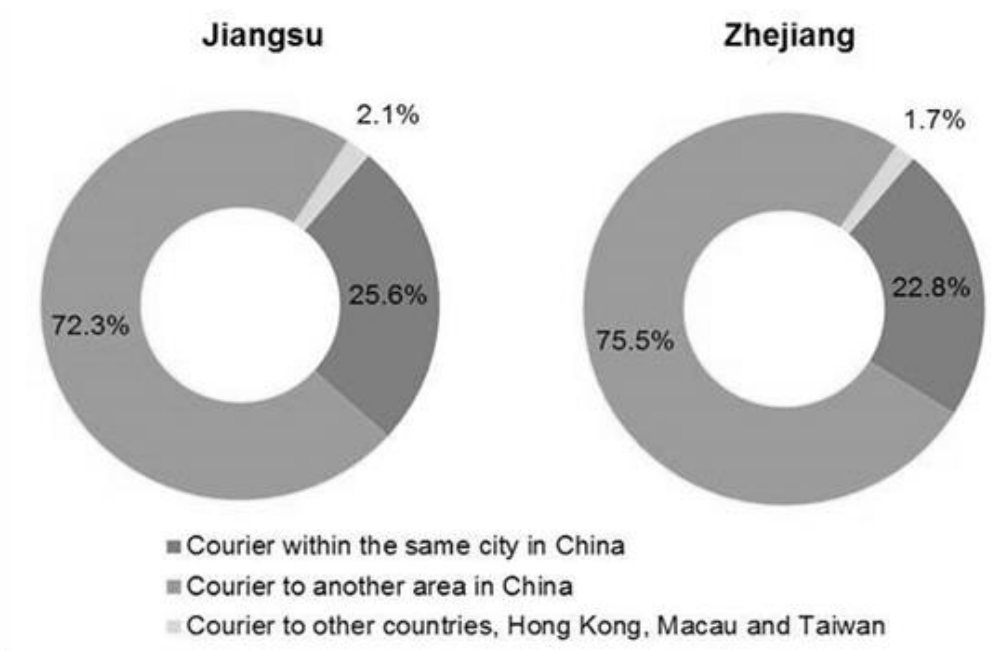

Figure 2: The situation of management in enterprises in some areas of China 
The archive database can be divided into a full-text database and a catalog database. The former mainly performs digital image processing on the entire article of the collected file, while the latter uses the information input data of the file to retrieve the file information. In the composition of the database, it mainly includes the full text and the database of both aspects. The database technology can import and automatically manage the file directory and file directory of the file, thereby improving the efficiency of directory management of the file.

\section{Countermeasures for Information Management Informationization Based on Financial Sharing Mode}

\subsection{Platforms to strengthen project file management}

Archives information management integrates different levels of information resources, and realizes the exchange and sharing of different aspects of accounting file management based on financial sharing mode. On the one hand, it promotes the level of project management; on the other hand, it enhances the scientific and rational characteristics of project decision-making. For the transformation of China's enterprise structure at this stage, it can effectively reduce project management costs, improve the efficiency of project implementation, and further improve the quality of market control and human resources. It is also an important way for enterprises to make their internal vitality. By strengthening the platform of project file management, the project files can be upgraded in terms of management processes, systems, and personnel.

\subsection{Unified work standards and procedures}

The main measure of the modernization of archival work is the overall guarantee of the procedures for archival work. Through the implementation of modern and standardized file management, the file work becomes simpler, and the overall situation is unified from a chaotic state, and because the situation of repeated labor can be reduced, the level of file management can be improved to a large extent. And doing things according to the rules and regulations can make the file management workers reduce the error rate in the work, thus ensuring the collection, identification and storage of files, and ensuring a certain degree of efficiency.

$$
\alpha=\mathrm{SX}(1 \mathrm{nSX}) \sum \mathrm{DD}(\mathrm{Mni}-1 \mathrm{DD}) \alpha \mathrm{Wii}=\mathrm{SX}(\alpha 1 \mathrm{~W} 1+\alpha 2 \mathrm{~W} 2+\ldots+\alpha \mathrm{nWnSX})
$$

\section{Conclusions}

The informatization construction of file management can improve the quality of the overall project to a certain extent, and the use of information management methods can quickly establish a project file management system and account books, so that the file retrieval is faster and more accurate, thus achieving greater Resource sharing in the sense. At present, there are more and more modern courses in China, so the informationization of document management is becoming more and more important. Enterprises can carry out informatization project file management system by strengthening platform project file management, unifying work standards and procedures, implementing the whole process of synchronous tracking management, attaching importance to the introduction of technology and technology in file management, and improving the formulation of project file management system. Perfect.

\section{References}

[1] Diermeier D, Eraslan H, Merlo A. Bicameralism and Government Formation[J]. Pier Working Paper Archive, 
2016, 2(2004.81):227-252.

[2] Zhang H. The Research Based on Big Data Management Accounting Model Building[J]. 2017, 4(4):228.

[3] Zhao N N, Han B, Zhong Q H. The Financial Management of Small Micro Enterprises Based on Cloud Accounting in the Big Data Era[J]. Computer \& Information Technology, 2018. 